\title{
LIVED EXPERIENCE OF HIGH SCHOOL TEACHERS AMIDST COVID-19 PANDEMIC: A PHENOMENOLOGICAL STUDY
}

\author{
Michelle Sarah Kainama ${ }^{1}$, Anne Lou Hendriks² \\ 1,2 Universitas Advent Indonesia \\ ${ }^{1}$ michelleskainama@gmail.com, ${ }^{2}$ hendriksal@aiias.edu
}

\begin{abstract}
The purpose of this research was to discover the experiences of English teachers in Jayapura, Papua in terms of the execution of online learning during the COVID-19 pandemic. A qualitative method was used to find out the target needs related to teachers' experiences. The data collection used was semistructured interviews with five English teachers selected as the participants in this research. This research found English teachers experiences out regarding online classes that have been made in the outspread of COVID-19. The major results of this study showed there are several areas on teachers' experiences in performing online classes; interaction that is both high-quality and timely, technical issues, and the participation of the students.
\end{abstract}

Keywords: Experiences, English teacher, Online learning, COVID-19

\section{INTRODUCTION}

Teachers play a significant role education as reflected by various studies. (Madjid, 2020; Zhao, 2018;) support it and the interaction with the students and other member of school community. Teachers not only give knowledge but also play crucial role in boosting students' motivation. The World Health Organization (WHO) declared COVID-19 as a global health emergency international concern on 30th January 2020 and a pandemic on 11th March 2020 (As cited in Adnan \& Anwar, 2020). WHO (2020) recommended some standards such as social distancing and physical distancing to limit the spread of the virus.

Even thought, COVID-19 has extremely impacted every aspects, may it be-economics (Akbulaev et al., 2020; Borio, 2020; Chang et al., 2020; Fernandes, 2020), business (Bartik et al., 2020; Donthu \& Gustafsson, 2020; Seetharaman, 2020; Wellman et al., 2020) tourism (Bakar \& Rosbi, 2020; Foo et al., 2020; Rutynskyi \& Kushniruk, 2020; Škare et al., 2021), human psychology (Atalan, 2020; Kamal et al., 2020; Pillay \& Barnes, 2020; Si et al., 2020),(Kamal et al., 2020; Si et al., 2020) The world of education is also affected by the COVID-19 (Akat \& Karataş, 2020; Choi et al., 2020; Ferrel \& Ryan, 2020; Sintema, 2020). The COVID-19 pandemic has created the largest disruption of education systems in history, affecting nearly 1.6 billion learners in more than 190 countries and all continents (United Nations, 2020).

It is hoped that all educational institutions - schools, colleges and universities will shift in some way or another to online learning as a replacement for on-site delivery. With the COVID-19 pandemic, emergency online education system started. Online learning, means all of the subjects will be taught and learned online. In learning, interaction is very important. Classroom interaction is central in language teaching learning process (Sundari, 2017). 
A study (Marshall et al., 2020) claims that teachers found all aspects of teaching more challenging. Education in Jayapura, Papua also suffered because of this pandemic. It is undeniable that interaction between teachers and students in Jayapura is still lacking. With the implementation of distance education, teachers find it more difficult neither to interact nor using the technology. According to Rusmiati et al. (2020), a teacher must overcome all the problems that occur in online learning responsively so that the learning continues to achieve the targets set.

There are various tools that have been used for online classes such as Zoom, Whatsapp, Google meet and some more, in order to keep teachers and students interact. In this case, parents also have the important role in order to support their children such as helping them study- explain subject that cannot be understood, and provide a convince and comfortable place. In Jayapura, online learning that is internet-based system has never been done before and it is a new thing that is 'forced' to do. Teachers and students themselves have to deal with technology. Either teachers or students must have adequate facilities to participate in online learning but besides technology, it also has various problems such as internet network and also the cost to purchase data packages.

\section{Research Questions}

This research was conducted according to the following research questions:

1. What are the experiences that English teachers in Jayapura encounter while implementing online learning?

2. What are the significant differences between teaching online and teaching offline?

\section{METHOD}

This research will apply qualitative methodology-phenomenology study, that will explore teachers lived experiences of a phenomena. The purpose of the phenomenological approach is to illuminate the specific, to identify phenomena through how they are percieved by the actors in a situation (Lester, 1999). In qualitative research, the inquirer analyzes words such as transcriptions from interviews to analyze the data instead of statistics. Rather than relying on statistical procedures, the qualitative researcher analyzes the words to group them into larger meanings of understanding, such as codes, categories, or themes (Girik, 2020)

\section{Research Settings, Participants and Sampling}

This research was conducted in the East side of Indonesia-Jayapura, Papua. The participants of this research are teachers from the city and the district of Jayapura. Five participants were selected and agreed to participate in the study without being forced.

\section{Data Collection}

The research was conducted for one semester, and the data were collected through a semistructured online interviews via Whatsapp App to prevent the outspread of COVID-19. Not like structured interview questions which cannot be changed, interview questions that are semistructured may be changed if required to encourage participants to express their experiences (Creswell \& Poth, 2016; Patton, 2002). The participants were given six questions related to their experience in teaching before and after the outbreak of COVID-19. 


\section{RESULTS AND DISCUSSION}

\section{Results}

Table 1. Characteristic of the Participants

\begin{tabular}{ll}
\hline Characteristic & \\
\hline $\begin{array}{l}\text { Gender } \\
\text { - Female }\end{array}$ & 3 \\
- Male & 2 \\
Age & $26-53$ years old \\
Educational Status & Bachelor's \\
Position & English Teacher \\
School & 3 \\
$\qquad \quad$ Public School & 2 \\
$-\quad$ Private School & \\
\hline
\end{tabular}

Based on the first question given to the teachers, it shows that all of them had wonderful experiences while teaching both face-to-face and online. Some reasons given to the author about why the teachers had wonderful experiences.

"I've met students with different backgrounds, religions and cultures. I think it's unique." (Teacher 1)

"I have a lot of friends from I think all over Indonesia, and those are my students." (Teacher 2)

The answers of the second question shows that the teachers are struggling with the participation of the students, the limitation of time and the changing of methodology they use in teaching.

"We did things normally. Meet the students everyday, interact with them. It's different when COVID-19 hit. We have limitation of time." (Teacher 3)

"I used to had a short sharing time with my students before we begin the class and all the students participated. They were so active, but in this pandemic situation less than a half of the students participate even where we are talking about the materials." (Teacher 5)

"When I can directly meet the students in the classroom, the environment was really fun. The students, like it or not, had to be participated in whatever the activity was. Besides learning, we sometimes play games related to the topics. After the spread of COVID-19 I have to change the method of teaching, how to make the students still want to take the online classes seriously." (Teacher 4)

The third shows that the main disadvantages found in online class were the interaction, communication, and activeness of the students.

T1 : "We can not directly meet the students"

T2 : "Students are less active in learning. There were some students who know they are given task but they don't do it."

T3 : "We are lacking of physical interaction and communication, also concentration." 
T4 : "We have less interaction with the students. They are less active. I have to always remind them about the tuition fee."

T5 : "There were less of interaction and concentration. We also have unstable internet connectivity. Some students even don't have access to join the class meeting.

For the forth question, the teachers have the same answers - they are able to teach wherever they are and get more knowledge about computer.

T1 : "It's easier, don't need to go to school."

T2 : "Teachers know more about computer because it related to the online learning."

T3 : "I can teach my students everywhere. I also have the opportunity to develop my skill in using electronic devices.

T4 : "WFH (Work From Home) means I can teach wherever I am. In teaching online, teachers are more knowledgeable about computer things and know more about learning platforms."

T5 : "Teachers are able to teach wherever we are. I've even ever teach while I'm cooking. While teaching online, I don't use my voice too often like usual in the real classroom."

The answers of the fifth question show the teacher willing to teach even in the era of COVID19 that force them to teach online.

T1 : "I might still face the difficulties both from the development of teaching techniques and in my financial but it doesn't make my spirit down."

T2 : "I'll teach and give every method I can give so that the students won't feel bored and still want to take online classes."

T3 : "In the time of COVID-19, it forces me to do something different. As long as I have the chance to teach, I will still focus on this profession. For me this pandemic doesn't matter but it's a way to be more creative."

T4 : "If we still have to work from home, I won't let my teaching skills just like it is used to be. I will always develop my teaching skills, find methods to teach and try as hard as I could to improve my students' skill especially in English."

T5 : "Developing my teaching skill is a must. I'll do whatever it takes so that my students will get everything they have to get in the school from me."

The last question about if the teachers find joy in teaching online comes up with one same answer - they did find joy. Below are the asnwers:

T1 : "All must be faced with joy. I do find joy while teaching online."

T2 : "I am happy, because it breaks the chain of transmission of COVID-19."

T3 : "It's enjoyable because it can safe more my energy. In the other side, as a christian teacher, teaching is not only transfering the knowledge to the pupils, but the more important is the character. The value is very important."

T4 : "At first, I thought I would be a boring teacher because I'd never thought about teaching online. I tried my best in teaching online and until now I'm happy doing this job."

T5 : "Being a teacher brings joy to me. It has special place in me. Even though I have to teach online, I really enjoy teaching.

\section{Discussion}

Teachers have had a completely new teaching environment as a result of the abrupt transition from traditional classrooms and face-to-face learning to online learning. The outbreak of 
COVID-19 has changed the educational system from offline to online learning and not just the teachers and pupils but also parents have undoubtedly impacted. The result of this research based on the teachers responses found that face-to-face teaching process was more postive than online learning in term of social interaction, technical issues, and participation of the pupils. Teaching become very ineffective because there was dissatisfaction found in the teaching process. Though, the teachers still find joy during the online learning process.

\section{CONCLUSION}

The pandemic has created a dramatical effect to many people in the world. This issue difinitely affects teachers' experiences of teaching. The experience of the teachers must be seen as a guide in execution of online learning. It can be concluded that the experience of the teachers demonstrates it is both effective and ineffective in the middle of COVID-19 pandemic. Teachers as the role model should consider the learners' situation especially in selection of online learning applications and provide all aspects needed in online learning. Teachers must assist students in personalizing their learning environments and achieving their goals in learning.

\section{ACKNOWLEDGMENTS}

First, praises to God the Almighty Father for His never-ending-love and blessings given to the researchers to finish this article. We would like to show our gratitude to all the contributorsschool administrators, family and friends for the help and support throughout this research process. Last, we place on record, our sincere thanks to all, who directly and inderctly, have lent their hands in this work.

\section{REFERENCES}

Adnan, M., \& Anwar, K. (2020). Online Learning amid the COVID-19 Pandemic: Students' Perspectives. Online Submission, 2(1), 45-51.

Akat, M., \& Karataş, K. (2020). Psychological Effects of COVID-19 Pandemic on Society and Its Reflections on Education. Electronic Turkish Studies, 15(4).

Akbulaev, N., Mammadov, I., \& Aliyev, V. (2020). Economic impact of COVID-19. Sylwan, $164(5)$.

Atalan, A. (2020). Is the lockdown important to prevent the COVID-19 pandemic? Effects on psychology, environment and economy-perspective. Annals of Medicine and Surgery, 56, $38-42$.

Bakar, N. A., \& Rosbi, S. (2020). Effect of Coronavirus disease (COVID-19) to tourism industry. International Journal of Advanced Engineering Research and Science, 7(4), 189-193.

Bartik, A. W., Bertrand, M., Cullen, Z. B., Glaeser, E. L., Luca, M., \& Stanton, C. T. (2020). How are small businesses adjusting to COVID-19? Early evidence from a survey. National Bureau of Economic Research.

Borio, C. (2020). The Covid-19 economic crisis: Dangerously unique. Business Economics, 55(4), 181-190.

Chang, C.-L., McAleer, M., \& Wong, W.-K. (2020). Risk and Financial Management of COVID-19 in Business, Economics and Finance. Journal of Risk and Financial Management, 13(5), 102. https://doi.org/10.3390/jrfm13050102

Choi, B., Jegatheeswaran, L., Minocha, A., Alhilani, M., Nakhoul, M., \& Mutengesa, E. (2020). The impact of the COVID-19 pandemic on final year medical students in the United Kingdom: a national survey. BMC Medical Education, 20(1), 1-11. 
Creswell, J. W., \& Poth, C. N. (2016). Qualitative inquiry and research design: Choosing among five approaches. Sage publications.

Donthu, N., \& Gustafsson, A. (2020). Effects of COVID-19 on business and research. Journal of Business Research, 117, 284.

Fernandes, N. (2020). Economic effects of coronavirus outbreak (COVID-19) on the world economy. Available at SSRN 3557504.

Ferrel, M. N., \& Ryan, J. J. (2020). The Impact of COVID-19 on Medical Education. Cureus, 12(3), 10-13. https://doi.org/10.7759/cureus.7492

Foo, L.-P., Chin, M.-Y., Tan, K.-L., \& Phuah, K.-T. (2020). The impact of COVID-19 on tourism industry in Malaysia. Current Issues in Tourism, 1-5.

Girik, A. M. D. (2020). Is the online learning good in the midst of Covid-19 Pandemic. The Case of EFL Learners. J. Sinestesia, 10, 1-8.

Kamal, S. M., Al-Samydai, A., Yousif, R. O., \& Aburjai, T. (2020). International Journal of Research in Pharmaceutical Sciences.

Lester, S. (1999). An introduction to phenomenological research.

Marshall, D. T., Shannon, D. M., \& Love, S. M. (2020). How teachers experienced the COVID19 transition to remote instruction. Phi Delta Kappan, 102(3), 46-50. https://doi.org/10.1177/0031721720970702

Patton, M. Q. (2002). Qualitative Research \& Evaluation Methods . California: SagePublication. Inc.

Pillay, A. L., \& Barnes, B. R. (2020). Psychology and COVID-19: impacts, themes and way forward. South African Journal of Psychology, 50(2), 148-153.

Rusmiati, A. R., Reza, R., Achmad, S., Syaodih, E., Nurtanto, M., Sultan, A., Riana, A., \& Tambunan, S. (2020). The perceptions of primary school teachers of online learning during the COVID-19 pandemic period: A Case study in Indonesia. Journal of Ethnic and Cultural Studies, 7(2), 90-109.

Rutynskyi, M., \& Kushniruk, H. (2020). The impact of quarantine due to COVID-19 pandemic on the tourism industry in Lviv (Ukraine). Problems and Perspectives in Management, 18(2), 194.

Seetharaman, P. (2020). Business models shifts: Impact of Covid-19. International Journal of Information Management, 54, 102173.

Si, M.-Y., Su, X.-Y., Jiang, Y., Wang, W.-J., Gu, X.-F., Ma, L., Li, J., Zhang, S.-K., Ren, Z.F., \& Ren, R. (2020). Psychological impact of COVID-19 on medical care workers in China. Infectious Diseases of Poverty, 9(1), 1-13.

Sintema, E. J. (2020). Effect of COVID-19 on the performance of grade 12 students: Implications for STEM education. Eurasia Journal of Mathematics, Science and Technology Education, 16(7), em1851.

Škare, M., Soriano, D. R., \& Porada-Rochoń, M. (2021). Impact of COVID-19 on the travel and tourism industry. Technological Forecasting and Social Change, 163, 120469.

Sundari, H. (2017). Classroom interaction in teaching English as foreign language at lower secondary schools in Indonesia. Advances in Language and Literary Studies, 8(6), 147154.

Wellman, S., Moskal, J., Barnes, C. L., \& Parvizi, J. (2020). Business unusual: COVID-19 ramifications for arthroplasty. The Journal of Arthroplasty, 35(7), S1-S2. 